\title{
Assessment of the Impact of Foreign Aid on Economic Growth: Evidence From 26 HIPC Sub-Sahara African Countries
}

\author{
Yananga Phiri \\ Reserve Bank of Malawi, Malawi \\ Email: yphiri@rbm.mw \\ Betchani H. M. Tchereni \\ Regenesys Business School, RSA \\ Email: betchereni@gmail.com
}

Doi:10.5901/mjss.2013.v4n13p201

\begin{abstract}
The study examined the impact of foreign aid on economic growth using a sample of 26 HIPC countries from the Sub-Saharan Africa over the period 1980 to 2006. Using Random Effects method, the results show that firstly the initial level of income, investment, growth in labour force, government size, debt service and aid intensity are the main determinants of growth in SSA. Secondly the study finds evidence of a direct positive impact of aid intensity on economic growth being significantly different from zero. However, this direct impact does not compare favourably with the impact exerted by investment and government size on economic growth. Thus while the findings support moves by the G8 to double aid to developing countries including Africa, the need for Africa to industrialize remains a necessary precondition for the growth impact of aid to be meaningful.
\end{abstract}

Keywords: Economic growth, HIPC, Fixed effects, foreign aid

\section{Introduction}

The debate on aid-growth nexus has attracted attention among economists and private sector practitioners both in the developed and developing world. Stiglitz(2006) notes that business captains in developed countries view aid to poor countries as increasing their marginal propensity to tax, arguing that the more a donor country pledges in aid, the more their governments have to raise revenue, including through tax, to finance this aid. In developing countries, aid has been seen as an additional source of foreign exchange needed to import capital goods and raw materials for production as well as affording governments with resources necessary for infrastructure development that should attract more Foreign Direct Investment (FDI) (Bolton, 2008). Further, foreign aid has been seen as supplementing domestic savings to attain a required level of investment (Gymah-Brempong, 2004).

Hansen and Tarp (2000) and Collier \&Dehn (2001) support the view that foreign aid is effective at spurring economic growth in recipient countries. However, others including Mosley et al (1987) andMoyo (2009) are sceptical on the positive impact of aid on growth. They view foreign aid as augmenting corruption, supporting bad governments, displacing domestic savings, and crowdin-out FDI. The Sub Saharan African (SSA) region has been given a high priority for foreign aid since the late 1970s.According to World Bank (2006), SSAwas given on average, 22 percent of the total Official Development Assistance (ODA) in 1972-1982, rising to 31 percent in the second sub-period 1983-1993, before its share dropped slightly to 28 percent in the ten years 1994-2005. Data from the World Bank (2009) further indicates that the region absorbed on average 27 percent of total ODA to developing countries as a whole during the years 1972-2005, compared to 8 percent to Eastern Europe and Central Asia, 9 percent for Latin America, 13 percent for South Asia and 14 percent for East Asia.

Although aid to Africa has taken different forms and been given for different motives, available data seems to suggest that it failed translate into meaningful economic growth. Collier (2001) showed that between 1980 and 2004 aid to SSAtotalled $\$ 390$ billion while its economic performance remained weak. Given this thrust to double aid by 2015 , it is vital to examine how such increase will impact on economic growth in 26 Sub Saharan HIPC countries and corollary, how failure to meet such pledges will equally impact on the region. 
The main objective of this research was to examine the macroeconomic determinants of economic growth in 26 HIPC SSA over the period 1980 to 2006, paying particular attention to the impact of foreign aid on economic growth. The period under scrutiny saw a number of African countries adopting economic reforms that came about due to IMF supported Structural Adjustment Programmes. The paper is organised as follows; the next section provides theoretical literature review, section 3 gives empirical literature followed by methodology in section 4 . Section 5 concludes the paper.

\section{Theoretical Literature Review}

An account of the history of foreign aid draws heavily from works of Ali et al (1999) and Moyo (2009) who categorize aid into three broad categories namely: (i) humanitarian or emergency aid, (ii) charity based aid, and (iii) systematic aid either at the bilateral and/or multilateral level.Systematic aid accounts for much of aid transfers to poor countries in the form of conconcessional loans or grants (Killick and Foster 2007). However, Moyo (2009) notes that policy makers in poor economies do not strongly view the two as different since a large share of foreign loans are provided on highly concessional terms, and that loans are frequently forgiven.

Theorists view the effectiveness of aid in raising domestic investment as the main channel through which aid can help achieve sustainable economic growth. Generally, the aid-financed investment approach has its roots from the Harrod-Domar Gap Model, which postulates that growth is proportional to investment by a constant that is reciprocal to the incremental capital output ratio. Besides the physical capital formation limitation that Lewis (1954) and Rostow (1960) considered, Chenery and Strout (1966) incorporated domestic savings and foreign exchange as additional constraints to economic growth. This model estimates the amount of foreign capital flows required by a developing country to finance its requirements for investment and import of raw materials, capital machinery, intermediate goods and spare parts needed to achieve a certain rate of economic growth. They assert that since investment is financed from savings, developing countries do not have adequate domestic savings with which to attain the desired level of investment. Aid is viewed as an additional source of finance to satisfy this domestic savings gap.

However even if a developing country may have sufficient domestic savings to finance investment requirements, rigidities in the production and demand structures such as an overvalued exchange rate, relatively low price and income elasticity of world market demand for primary commodity exports inter-alialimit a country's ability to convert its redundantpotential savings into the required foreign exchange earnings necessary to support its production related imports. Developing countries do not generate the required level of export proceeds to sustain import demand. In view of this foreign aid could be used to close the foreign exchange gap (Chenery and Strout, 1966).However as noted by Morrisey and White (1996), the model's assumption of limited flexibility in the productive system, and in the composition of aggregate demand for domestic and imported goods and services were questioned. In addition, the model has been faulted as being too simplistic to adequately capture various complexities in the relationship between foreign aid and the macro-economy.

Griffin (1970) argued that foreign aid would displace savings, such that aid inflow would not raise domestic savings in the same magnitude as the value of the aid. He used the accounting identity that savings equals income minus consumption and asserted that an increase in aid would increase consumption and therefore reduce savings. Heller (1975) developed a model of aid's impact on public savings, citing that aid would finance lower taxes. As taxes fall while current expenditure rises by less than the value of aid inflows, the net impact on public savings would be ambiguous. Ruhashyankiko (2005) argue that governments were the main recipients of aid and that therefore their fiscal behavior had far reaching implications on private investment. Bacha (1990) and Taylor (1993) recognize that restrictions on government expenditures would constrain the level of public sector investment and negatively impact on private investment. As government investment is assumed to be determined by capital or aid inflows among other factors, foreign aid is therefore perceived to augment private investment if there are crowding-in effects from public investment. Aid financed public investment in infrastructure is likely to have crowd-in effects than when government uses resources from the domestic banking system which might be at the expense of the private sector.

Other studies however have considered the impact of aid on growth as channelled through financing reforms to remove structural rigidities and so help streamline trade and financial intermediation. Aid that supports reform may crowd-in other foreign inflows that may help in the growth process. Such reform may help improve a country's credit worthiness. However, World Bank (1992) recognizes a lagged effect of this impact, citing that while reforms increase country's ability to use foreign savings productively, there are long lags between the execution of the reforms and international capital markets and bilateral lenders to recognize the good performance arising from the reform. As a result, this leaves a balance of payment gap that needs to be filled for growth to occur. Indeed, UNDP (2006) argues that if aid 
recipients are called upon to liberalize trade, either as conditionality or as a means to better absorb aid inflows, there is a strong likelihood for a fall in trade tax revenue. Thus aid tied to reform may complicate domestic resource mobilization.

\section{Empirical Literature Review}

From the foregoing theoretical literature, it can be noted that the much of the aid-growth debate has cantered on aspects of investment augmentation, balance of payment support, sound macroeconomic policy environment, reform, government consumption expenditure patterns and its impact on real exchange rate and export competitiveness. The preceding empirical literature examines these key aspects in the context of the SSA region. In a study of 22 SSA countries, Levy (1988) found that an extra dollar of aid was associated with 1.08 additional dollars of investment. This study covered the period 1968 to 1982. However, for the same SSA countries for the period 1968 to 1987, GyimahBrempong (1992) found that aid had a small but significant and positive effect on economic growth. His simultaneous equation approach established that the impact of aid on growth was both direct as well as indirect via increase in domestic savings and domestic investment. Gomanneet al (2005) used pooled panel data for 25 SSA countries over the period 1970 to 1997. The findings identified investment as the most significant transmission mechanism through which aid impacts economic growth. They also considered effects of aid through financing of imports and government consumption spending.

Other studies have revealed a non-positive link between aid and growth. For instance, Rajan and Subramanian (2005a) found no evidence of a robust correlation between aid and annual average growth rate of per capita GDP. In addition, they did not find empirical support that certain type of aid works better than others. This serves to support the view by Easterly (1999) that aid does not necessarily lead to higher investment and that the investment-growth link in African countries in particular tends to be more complicated than the financial gap model assumes. In addition, Van der Hoeven\&Lubker (2006) note that the investment-growth nexus is further complicated by the increased lock up of aid in official reserves, citing that for SSA, reserve holdings as a percentage of GNI rose from 5 percent in early 1990s to around 12 percent a decade later. On the growth impact of aid via reform, the evidence is equally mixed. Using a sample of 58 countries of which 23 were from Africa over the period $1965-1999$, Chauvet (2005) concluded that aid might protect countries that are vulnerable to external trade shocks as well as regional political shocks, citing that aid in such countries prevents reform reversals while mitigating the harmful effects of these vulnerabilities. However, UNDP (2005) contends that aid may not help offset the effects of external shocks especially in Africa. They view aid itself as sometimes provoking shocks and volatility in the recipient economies since disbursements usually tend to be persistently lower than commitments. They also assert that aid outcomes usually fluctuate depending on the donor countries changing policies and economic cycles.

To strengthen the aid-reform view, Kasekende\& Ego (1999) caution that aid should not be used to buy reform but rather to finance reform. In their assessment of the Uganda's experience with aid, the authors emphasize that domestic ownership of the reform is more critical for its success than using reform as conditionality to aid. Where reforms are not domestically owned but only influenced by aid conditionality, the likelihood of slippages and reversal is large. As rightly observed by Asiedu (2001), a number of countries that embark on reforms as part of aid conditionality tend to abandon the reform at the expiry of the aid since they find little incentives to carry on.

With regard to aid and government, the debate has drawn heavily from analyses of impact of aid on increasing government consumption on non-tradables which leads to poor balance of payment positions. The debate has also taken the aid fungibility path to consider government behaviour in terms of adherence to agreed upon priorities. It does not come as a surprise, therefore, that similar studies for SSA found positive relationship between foreign aid inflows and real exchange rate appreciation. For instance, using time series analysis for Tanzania from 1967 to 1993, Nyoni (1998) found that aid inflows caused real exchange rate depreciation because much of the aid was tied to or made conditional upon the recipient country to import from the donor and fulfil outward oriented economic reform. Ouattara \& Strobl (2004), analysed panel data for 12 countries in the CFA Franc Zone over the period 1980 to 2000 and found that aid inflows were positively associated with real effective exchange rate, Nwachukwu (2007) used annual pooled data for 24 SSA countries that span from 1978 to 2001 and found that doubling of the share in GDP of the autonomous component of net external would cause on average a real exchange rate depreciation of around 8 percent. Burnside \& Dollar (2000) undertook aid-growth studies which, besides traditional factors used in standard neo classical growth models, also included economic policy, institutional and political variables. The study concluded that aid was more effective in countries with good economic policy environment as well as institutional framework such as strong rule of law and bureaucracy. Hansen \& Tarp (2000), Collier and Dollar (2001), Easterly (2003) and Dalgaard et al (2004) confirmed the 
effectiveness of aid in the presence of strong policies and institutions.

\section{Methodology and Data}

The data used in this study consists of unbalanced panel data from 26 HIPC countries in Sub Saharan Africa over nine 3 year-time periods from [1980-82] to [2004-2006] obtained from the World Bank and IMF. Panel estimation has been preferred as it saves a large number of degrees of freedom compared to cross country regression. Besides data availability, the choice of this sample was motivated by efforts that have been made by the region to adhere to good macroeconomic policy management and the various strides in structural reforms that the region embraced during this time frame.

\subsection{Model specification}

Our model draws heavily from the Neo-classical growth equations that according to Asteriou (2008), assume that real output can be represented by a Cobb-Douglas production function of the following form:

$$
Y_{x t}=A_{x t} K_{x t}^{1-\theta} L_{x t}^{\theta}
$$

Where the standard notation is used, $Y$ is output $K$ and $L$ denote stock of capital and the labour input, respectively. Equation (1) can be re-written as

$$
\frac{Y_{x t}}{A_{x t}^{1 / \theta}}=\left(\frac{Y_{x t}}{A_{x t}^{1 / \theta}}\right)^{1-\theta} L_{x t}^{\theta}
$$

Taking logs from both sides of simplified form of equation (2) we obtain equation 3 below.

$y_{x t}=(1-\theta) k_{x t}+\theta l_{x t}$

In equation 3 the lower case letters denote logarithmic variables.It is assumed that the capital accumulation process is given by:

$$
\begin{aligned}
& k_{x t}=(1-\delta) k_{x t-1}=i_{x t}+w_{x t} \\
& k_{x t}=(1-\gamma L)=i_{x t}+w_{x t} \\
& k_{x t}=(1-\gamma L)^{-1}\left(i_{x t}+w_{x t}\right)
\end{aligned}
$$

Where $\delta$ is the depreciation rate of capital, it denotes domestic investment and $w_{t}$ denotes aid coming from abroad. Further, aid $\left(w_{t}\right)$ is assumed to follow an autoregressive process given by

$$
w_{x t}=w+\rho w_{x t-1}+\mu_{x t} \text { where } \mu_{x t} \sim \mathrm{N}\left(0, \sigma_{\mu}\right)
$$

Substituting equations (4) and (5) into (3) with algebraic manipulations results in:

$$
\begin{gathered}
y_{x t}=(1-\theta)\left\{(1-\gamma L)^{-1}\left(i_{x t}+w_{x t}+\rho w_{x t-1}+\mu_{x t}\right)\right\}+\theta l_{x t}, \\
y_{x t}=(1-\theta) w+\gamma y_{x t-1}+(1-\theta) i_{x t}+(1-\theta) \rho w_{x t-1}+\theta l_{x t}-\gamma \theta l_{x t-1}+(1-\theta) \mu_{x t} \\
\left.y_{x t}=c+\gamma y_{x t-1}+(1-\theta), \theta, 0\right) x_{x t}+\{(1-\theta),-\gamma \theta,(1-\theta) \rho) x_{x t-1}+v_{x t}
\end{gathered}
$$

Where $x_{x t}=\left(i_{x t}, I_{x t}, w_{x t}\right)$. At the level of theory, equation (6) is the estimating model, relating output growth to the share of saving to GDP, the share of foreign aid to GDP and employment growth. However, as noted by Nwachukwu (2007), the standard package of structural adjustment reforms that characterize the period of our study sample comprised in large part, the following as measures to contribute to economic growth; trade liberalization, creation of flexible exchange rate market, deregulation of domestic markets, inflation stabilization plans which included fiscal austerity and control of aggregate money supply. Building on equation (6) above and following Dalgaard et al (2004) equation (7) below is adopted for empirical analysis:

$$
\begin{gathered}
Y G R=\alpha+\eta_{0} L N\left(1 Y_{0}\right)+\eta_{1} L N(P G R+g+\delta)+\eta_{2} L N(H C) X \theta_{1}+X_{1}+ \\
Y G R=\alpha+\eta_{0} L N\left(Y_{0}\right)+\eta_{1} L N(1 Y)+\eta_{2} L N(P G R+g+\delta)+\eta_{4} L N(H C) X \theta_{1}+X 1+\theta_{2} X 2 \ldots+\theta_{3} X_{4}+\ldots \ldots \theta_{n} X_{n} \ldots \ldots
\end{gathered}
$$

Where YGR is per capita real GDP growth rate, $1 Y$ is the ratio of investment to GDP, PGR is the rate of growth of labour force, $\mathrm{HC}$ is the selected indicator of human capital (such as life expectancy), school enrolment rate etc) and $X_{1}$ $X_{n}$ is a vector of selected indicators of macroeconomic policy, external conditions, governance, institutions and geography mentioned above. The terms $\eta_{0}, \eta_{1}, \eta_{2}, \eta_{3}$ in equation (8) are the elasticities of per capita income with respect to investment, growth in labour force and human capital. The coefficients $\theta_{1}$ $\theta_{n}$ represent the elasticities of per capita income with respect to changes in each of the selected $X_{1} \ldots \ldots X_{n}$ variables. They measure the expected percentage change in the dependent variable (i.e., per capita income growth rate) resulting from a one percentage increase in the independent $X$ variable of interest (say foreign aid ratio to GDP) when the values of all other independent variables are held constant. 
Table 1: Model Summary

\begin{tabular}{|c|c|c|}
\hline Variables & Definition & Expected Sign of coefficient \\
\hline $\begin{array}{l}\text { Real per Capita } \\
\text { GDP growth rate } \\
\text { (GDPPK }\end{array}$ & $\begin{array}{l}\text { This is the annual percentage growth rate in real } \\
\text { GDP per capita based on year } 2000 \text { constant local } \\
\text { currency In this regard, GDP per capita is gross } \\
\text { domestic product divided by midyear population. }\end{array}$ & $\begin{array}{l}\text { This is the dependent variable against which the } \\
\text { dependent variables will be compared in terms of } \\
\text { expected sign of their coefficients }\end{array}$ \\
\hline \begin{tabular}{|l|} 
Initial level of \\
income $\left(R G D P_{x t}\right)$
\end{tabular} & $\begin{array}{l}\text { This is GDP at constant } 2000 \text { US dollar lagged one } \\
\text { year. The analysis looks at real GDP as the initial } \\
\text { level of income and so is represented by real GDP } \\
\text { at constant } 200 \text { US dollar lagged one year }\end{array}$ & $\begin{array}{l}\text { The expected sign is positive. Since the present level of } \\
\text { growth builds on the past level of output. }\end{array}$ \\
\hline $\begin{array}{l}\text { Capital } \\
\text { Formation } \\
\text { (KFOMYxt) }\end{array}$ & $\begin{array}{l}\text { This is Fraction of level of income that is invested } \\
\text { in physical capital, expressed as a percentage of } \\
\text { GDP. It consists of outlays on additions to the fixed } \\
\text { assets of the economy plus net changes in the } \\
\text { level of inventories. }\end{array}$ & $\begin{array}{l}\text { A positive relationship is expected since at a given level } \\
\text { of population, an increase in the ratio of investment to } \\
\text { GDP is expected to increase the level of capital to labour } \\
\text { ratio and hence to increase productivity. }\end{array}$ \\
\hline $\begin{array}{l}\text { Population } \\
\text { growth } \\
\text { (POPGR5xt) }\end{array}$ & $\begin{array}{l}\text { This is the rate of growth of population, after } \\
\text { adjusting for exogenous growth in technology and } \\
\text { capital depreciation. The variable has been used to } \\
\text { proxy growth in the labour force. }\end{array}$ & $\begin{array}{l}\text { A positive relationship is expected since it increases the } \\
\text { productivity of capital and hence total output. }\end{array}$ \\
\hline $\begin{array}{l}\text { Trade openness } \\
\left(\text { TRADY }_{\mathrm{xt}}\right)\end{array}$ & $\begin{array}{l}\text { This is the sum of imports and exports of goods } \\
\text { and services expressed as a percentage of GDP. It } \\
\text { is a proxy for trade liberalization, one of the } \\
\text { conditions under the Structural Adjustment } \\
\text { Programs }\end{array}$ & $\begin{array}{l}\text { A positive relationship with growth is expected since } \\
\text { trade openness entails removal of structural bottles that } \\
\text { impede trade and transfer of resources }\end{array}$ \\
\hline $\begin{array}{l}\text { Government Size } \\
\left.\text { (GOVTY } Y_{\mathrm{xt}}\right)\end{array}$ & $\begin{array}{l}\text { This is Government Final Consumption } \\
\text { Expenditure (including all government current } \\
\text { expenditure for purchase of goods and services) } \\
\text { expressed as a percentage of GDP. As suggested } \\
\text { by Eastery \& Rebelo (1993), it is used as an } \\
\text { indicator of government size. Smaller government } \\
\text { size, reflecting austerity serves as one measure of } \\
\text { good government policy. }\end{array}$ & $\begin{array}{l}\text { The expected sign is negative. As noted by Ali (1999), a } \\
\text { high ratio of government expenditure to GDP has often } \\
\text { been associated with budgetary and balance of payment } \\
\text { imbalances that are likely to produce a climate of } \\
\text { economic uncertainty and stagnation and further } \\
\text { constrain government capacity to manage the economy } \\
\text { and thus should be negatively related o growth. On the } \\
\text { strength of this negativity, a high ratio of government } \\
\text { expenditure to GDP may imply higher expenditure on } \\
\text { non tradables away from tradables, thus negatively } \\
\text { affecting export competitiveness which may dampen } \\
\text { growth prospects- }\end{array}$ \\
\hline Variables & \begin{tabular}{|c|} 
Definition \\
\end{tabular} & Expected Sign of coefficient \\
\hline $\begin{array}{l}\text { Debt Service } \\
\text { (DBTSE } \text { (Dt) }^{\text {D }}\end{array}$ & $\begin{array}{l}\text { This is the sum of principal repayment and interest } \\
\text { actually paid in foreign currency, goods or services } \\
\text { on long term debt, interest paid on short term debt, } \\
\text { and repayments to the IMF. This is expressed as a } \\
\text { percentage of export of goods and services. }\end{array}$ & $\begin{array}{l}\text { An increase in the ratio means more forgone inflows } \\
\text { earmarked to debt repayment that would have otherwise } \\
\text { been used to finance domestic investment. In this } \\
\text { regard, debt service should be negatively related to } \\
\text { growth. }\end{array}$ \\
\hline $\begin{array}{l}\text { Index for political } \\
\text { freedom }\left(\mathrm{PF}_{\mathrm{xt}}\right)\end{array}$ & $\begin{array}{l}\text { This is measured on a } 1 \text { to } 7 \text { scale. } 1 \text { represents } \\
\text { the highest degree of freedom entailing regulatory } \\
\text { transparency, abolition of such anti investment } \\
\text { laws like forfeiture act, giving citizen freedom to } \\
\text { economic empowerment }\end{array}$ & $\begin{array}{l}\text { The expected sign is negative in so far as a high value of } \\
\text { the index represents less freedom to economic } \\
\text { empowerment among the citizens, lack of regulatory } \\
\text { transparency and certainty for investors. }\end{array}$ \\
\hline $\begin{array}{l}\text { Crop Production } \\
\text { Index }\left(\mathrm{CROP}_{\mathrm{xt}}\right)\end{array}$ & $\begin{array}{l}\text { This is an index that shows agricultural production } \\
\text { for each year relative to the base period 1999- } \\
\text { 2001. It includes all crops except fodder crops. }\end{array}$ & $\begin{array}{l}\text { As subsistence agriculture and agro export forms the } \\
\text { mainstay of most sub Saharan Africa economies, it is } \\
\text { expected that the index of crop production will be } \\
\text { positively related to economic growth }\end{array}$ \\
\hline $\begin{array}{l}\text { Official } \\
\text { Development } \\
\text { Assistance } \\
\left(\mathrm{ODAY} \mathrm{Y}_{\mathrm{x}}\right)\end{array}$ & $\begin{array}{l}\text { This consists of total disbursements of } \\
\text { concessional loans and grants by multilateral } \\
\text { institutions and non DAC Countries expressed as a } \\
\text { percentage of recipient country's GDP }\end{array}$ & $\begin{array}{l}\text { The expected sign is ambiguous. On the one hand ODA } \\
\text { is seen as pro growth as it compliments domestic } \\
\text { savings for investment finance. On the other hand, aid is } \\
\text { seen as fueling corruption, capital flight, bad } \\
\text { governments, Dutch disease etc and so seen as being } \\
\text { anti growth. }\end{array}$ \\
\hline
\end{tabular}




\subsection{Estimation technique}

A Random Effects Generalized Least Square Models of foreign aid and economic growth were adopted for the empirical study. In the spirit of Fayissa (1999) and Nwachukwu (2007), the 3 year time arithmetic averages was used with the view to eliminate short term cyclical fluctuations.For each series, a test for stationary was conducted to examine the order of integration of the variables. This study uses the Levin-lin-Chu panel unit root test developed by Levin, Lin \& Chu (2002). From the Levin-Lin-Chu Test results presented in Table 4, the series that can be used by our study to provide meaningful results are levels of GDP per capita growth, growth in population, index for political freedoms, index for crop production and logarithmic form of foreign aid, initial level of income, government size, debt service, terms of trade and trade openness.

\subsection{Empirical findings and interpretation of results}

The summary statistics of the variables as presented in Appendix 5, shows that a high level of diversity exists in our sample of 26 HIPC countries in the SSA region. Indeed, this does not come as a surprise given that our analysis of the raw data showed that GDP per capita growth averaged 0.08 percent with minimum of -12.58 for Democratic Republic of Congo 1992-94 and maximum growth rate of 17.37 for Liberia 1998-2000. In terms of capital formation, the mean was 16.73 with a minimum of 2.88 for Democratic Republic Congo during 1998-2000 and maximum of 50.93 for Chad 20012003. Terms of trade averaged 1.08 with a minimum of 0.16 during 1980-82 for Benin and maximum of 5.73 in 19861988 for Gambia. Index for Crop production averaged 83.82 with minimum of 27.5 in 1980/82 for Benin with 131.77 as the maximum in Sierra Leone 1989-1991. Government size averaged 13.22, with minimum of 5.02 in 2005/07 for Chad and a maximum of 36.6 in 1983/5 for Gambia. Debt service averaged 18.25 with a minimum value of 1.78 for Togo in $2004 / 6$ and maximum of 74.6 for Uganda in 1989/91. With regard to aid intensity, the average was 14.63, with a lowest value of 0.77 in 1983/5 for Guinea and maximum 63 in 1992/4 for Mozambique. The sum of imports and exports as a percentage of GDP averaged 60 percent with a minimum of 11.34 for Ghana 198/2 and a maximum value of 138.38 for Congo Rep 2004/6.

The results in Table 4 below show that the t statistic for GDPPKG, POPGR5, PF, CROP in levels and log of ODAY, RGDP, GVTY, DBTSE, TOT and TRADY at $1 \%$ are greater than the absolute critical values. We therefore reject the null hypothesis of non-stationarity.

Table 4: Levin Lin Chu unit root test results

\begin{tabular}{|c|c|c|c|c|c|}
\hline Variable & Coefficient & $\mathrm{t}$-value & $\mathrm{t}$-star & $\mathrm{p}>\mathbf{t}$ & Order of Integration \\
\hline LRGDPK & -0.40215 & -15.005 & -11.157 & 0 & $\mathrm{I}(0)$ \\
\hline LKFOMY & -0.60913 & -13.256 & -8.1607 & 0 & $\mathrm{I}(0)$ \\
\hline POPGR5 & -0.79769 & -19.335 & -14.666 & 0 & $\mathrm{I}(0)$ \\
\hline LTOT & -1.03442 & -33.524 & -33.059 & 0 & $\mathrm{I}(0)$ \\
\hline CROP & -0.35381 & -11.384 & -7.2926 & 0 & $\mathrm{I}(0)$ \\
\hline LODAY & -0.34181 & -18.673 & -17.565 & 0 & $\mathrm{I}(0)$ \\
\hline LGVTY & -0.53794 & -7.493 & 1.48878 & 0.9317 & $\mathrm{I}(0)$ \\
\hline LTRADY & -0.53876 & -8.839 & -3.6385 & 0.0001 & $\mathrm{I}(0)$ \\
\hline PF & -0.61026 & -14.757 & -10.602 & 0 & $\mathrm{I}(0)$ \\
\hline LDBTSE & -0.18494 & -3.414 & 4.44863 & 1 & $\mathrm{I}(0)$ \\
\hline
\end{tabular}

Given the above listed levels of integration, a set of models were estimated to test the impact of official development assistance on economic growth. The results are summarized in Table 5 overleaf.

Table 5: Summary of Regression Results

\begin{tabular}{|c|c|c|c|}
\hline & Model 1 & Model 2 & Model 3 \\
\hline Variables & Random Effects (without Aid Intensity) & Random Effects (With Aid Intensity) & Fixed effects (with Aid Intensity) \\
\hline Lrgdp & $-0.0648(-0.21)$ & $\mathbf{0 . 4 7 1 1}(\mathbf{1 . 6 7})^{*}$ & $-1.0422(-0.66)$ \\
\hline Crop & $0.0100(0.76)$ & $\mathbf{0 . 0 0 3 2 ( 0 . 2 6 )}$ & $0.0179(0.74)$ \\
\hline Pf & $--0.3168(-1.69)^{\star}$ & $-\mathbf{0 . 1 8 1 8 ( - 1 . 0 3 )}$ & $-0.1404(-0.78)$ \\
\hline
\end{tabular}




\begin{tabular}{|c|c|c|c|}
\hline Popgr5 & $0.7157(2.10)^{\star \star}$ & $0.8032(2.39)^{* \star *}$ & $0.8931(2.79)^{\star \star \star}$ \\
\hline Lkfomy & $2.7139(2.90)^{\star \star \star}$ & $2.4051(2.77)^{* * \star}$ & $2.1575(1.81)^{\star}$ \\
\hline Lgvty & $-2.0026(-2.65)^{\star \star \star}$ & $-2.3161(-3.23)^{* *}$ & $-3.6230(-4.03)^{\star \star \star}$ \\
\hline Ltrady & $0.1400(0.21)$ & $0.2820(0.48)$ & $1.7473(1.29)$ \\
\hline Ltot & $-0.6865(-1.00)$ & $-0.57039(-0.89)$ & $-0.1078(-0.15)$ \\
\hline Ldbtse & $-0.3483(-1.08)$ & $-0.5392(-1.62)^{*}$ & $-0.4571(-0.87)$ \\
\hline Loday & & $1.3275(3.02)^{* * *}$ & $1.1805(2.36)^{\star \star}$ \\
\hline Constant & $-5.3944(0.68)$ & $-19.35(-2.74)^{\star \star \star}$ & $9.3227(0.27)$ \\
\hline Rsq within & 0.1932 & 0.2256 & 0.2441 \\
\hline Rsqbtwn & 0.1745 & 0.2428 & 0.0069 \\
\hline Rsq overall & 0.1864 & 0.2249 & 0.1282 \\
\hline
\end{tabular}

Note: Figures in parenthesis are $z$ statistics for random effects and $t$ statistics for fixed effects, ${ }^{* * *}$ denotes significant at $1 \%,{ }^{* *}$ at $5 \%$ and * at $10 \%$, Dependent variable is GDP per capita growth rate (GDPPKG), Number of observations is 234 and number of groups is 26

\subsection{Interpretation of results}

Our empirical findings as averred in Table 5 indicate that our main model (MODEL 2) explains only 22.5 percent of the variations in GDP per capita growth, with overall $\mathrm{R}$ squared of 0.2249 . For cross sectional regression, such $\mathrm{R}$ square according to Cleeve (2008) and Woodridge (2006b) is considered fairly acceptable. Indeed, Gyimah-Brempong (1992) notes that such low explanatory power is common to estimates of growth equations in LDCs that use cross national data. This considered, studies have also tended to look at other measures like the standard deviation and coefficient of variation. With a larger standard deviation pointing to low data quality for cross sections and vice versa for small standard deviation. Our regression results have standard errors that are robust to hereroskedasticity in so far as they were adjusted for 26 clusters in code.

According to our sample of 26 HIPC Sub Saharan Africa countries, the main determinants of economic growth in descending order of importance are investment or capital formation, government size, aid intensity, growth in labour force, debt service and initial level of income. Except for initial level of income and debt service that were significant at $a=0.10$, the rest of the above variables were significant even at $\alpha=0.01$. The intercept was found to be -19.35 , at one percent level of significance. This implies that holding other factors constant, the expected level of growth in GDP per capita stands at negative 19 percent. This makes economic sense bearing in mind the consuming population, environmental degradation, resource depletion and wastage that often accompany economic growth. Initial level of income was found to be positively related to economic growth. Statistically significant at $10 \%$, a 1 percent increase in initial level of income, ceteris paribus, led to growth in GDP per capita of 0.5 percent. The thinking is that current level of growth will build on previous levels of income.

In the same vein, the findings confirmed the expected positive sign of investment. Significant at $1 \%$, a 1 percent increase in gross capital formation as a percentage of GDP led to growth in GDP per capita by 2.4 percent, ceteris paribus. The above findings make economic sense considering that expansion of credit to private sector be it for working capital needs or seed capital has a bearing on the growth of the private sector, which is touted the engine for economic growth. At a given level of population, an increase in investment to GDP ratio increases the level of capital to labour ratio and hence an increase in productivity.

A unit increase in the index for crop production led to an increase in economic growth of 0.32 percent, not even statistically significant. It does not come as a surprise that the impact of crop production index on economic growth is minimal and statistically insignificant since production for export in most Sub Saharan African countries constitute primary products which suffer adverse terms of trade in form of falling international prices, quota restrictions, sanitary and phytosanitary measures as well as general inelastic demand on international markets. There is therefore the need to graduate from production of primary commodities to now venture into value adding processed exports. Growth in labor force was also found to be positively related to economic growth. Ceteris paribus, a unit increase in population growth, adjusted for exogenous growth in technology and capital accumulation, as a proxy for growth in labor force led to growth in GDP per capita by 8.03 percent, at $\mathrm{a}=0.01$. In line with theory, a positive relationship with growth was expected since growth in labour force increases the productivity of capital and hence output.

Also in line with theory, government size was found to be inversely related to growth. At one percent level of significance, a one percent increase in government size, ceteris paribus, led to reduction in GDP per capita by 2.3 percent, at one percent level of significance. Government size has the effect of crowding out private sector since the 
credit that should have been available for private sector financing is earmarked to finance the government deficit and thus deny private sector to effectively execute its growth engine role. In addition, government size, has a dampening effect in that in creating demand for credit, it thus contributes to an increase in interest rates, inflation, and even exchange rate depreciation especially where external borrowing has to be sourced to supplement domestic financing. Uncertainty in the exchange rates not only does it make planning difficult for private sector but it entails private sector sourcing capital goods and raw materials at relatively higher costs; imported inflation.

Closely linked to this is debt service. A one percentage increase debt repayment as a percentage of export, ceteris paribus, was found to lead to a reduction in growth in GDP per capita by 0.5 percent, significant at 10 percent. The theoretical explanation for this is that where government borrowed externally to finance the deficit, much of the export proceeds that should have otherwise been used to provide the much needed foreign exchange for importation of raw materials and machinery, tends to be rechanneled to instead service external debt. Thus the private sector is constrained in its growth engine role. Index for Political freedom was found to be negatively related to economic growth. Ceteris paribus, a unit increase in the index, implying wars, corruption, autocratic rule, crime, lack of enforcement of regulations and uncertainty in fair trading practices led to a drop in growth by 0.18 percent. Thus worsening of the index means that the private sector is not free to do business with certainty as it is not certain that their investment is safe from forfeitures, or that foreign direct investment will be at liberty to externalize their dividends, profit or when winding up . it further implies that there are no ready, transparent and just legal system to settle disputes as they arise or that contracts will be enforced.

Trade openness, albeit not statistically significant, was found to be positively related to economic growth with a percentage increase in openness leading to growth by 0.28 percent. The minimal impact could infer that much of the trade in our sample is of primary products and thus suffering adverse terms of trade.Aid intensity, our main variable under discussion was found to positively impact on economic growth. Significant at 1 percent, a one percentage increase in official development assistance as a percentage of GDP was, ceteris paribus, found to lead to an increase in GDP per capita by 1.38 percent. The findings were also robust under the Fixed effects Model where at 5 percent significance level, a one percentage increase in aid intensity was found to positively impact on growth in GDP per capita by 1.18 percent.

The fact that this direct impact of aid on growth has been found to be minimal relative to other key variables, at best, could suggest that aid cannot be a major source of long-term economic growth in our sample. It can merely accelerate the pace of economic growth through its impact on the key variables as propounded by theory. As alluded to under literature review, such variables include capital formation, initial level of income, debt service, growth in labour force and government size. These variables were found to be significant, most of them even at $a=0.01$. The positive impact of aid intensity on economic growth should be viewed in the context of increasing the initial level of income that increases purchasing power of households to demand goods and services and hence ensure producers of a ready market for their goods. It has also gone a long way in financing improved delivery of health sector and education sector needs for a skilled and health labour force. In addition, aid has helped supplement domestic savings through availability of foreign exchange to support the importation of raw materials, machinery and other private sector investment needs.

\section{Conclusion and Recommendations}

The primary objective of this research was to analyse the impact of foreign aid on economic growth using evidence from 26 HIPC SSA countries. The results indicate evidence of a direct positive impact of foreign aid on economic growth. However, this impact on economic growth does not compare favourably with that of capital formation and government size. Other key determinants of economic growth were growth in labour force, debt service and initial level of income. The results suggest that aid cannot be a major source of long-term economic growth in SSA. The SSA should therefore not solely depend on foreign aid to fuel economic growth. Economic aid should only help to accelerate the growth rate in these countries through its effect on such key variables as capital formation, government size, labour productivity, debt service and initial level of income.

As capital formation has been found to be major determinant of growth, it is recommended that efforts aimed at improving the efficiency of the private sector should be encouraged. It is also imperative that aid should be used to build foreign reserves to ensure availability of foreign exchange for key private sector imports of capital goods and raw materials. It is acknowledged that most developing countries heavily rely on agriculture as the primary source of export earnings. Yet in our sample, the coefficient of crop production index albeit positive was not statistically significant. Aid financed reform measures should target the transformation of the agriculture sector for value adding agro processing of finished goods for export rather than for primary goods export. This should also cover empowerment of local SMEs with 
capacity building initiatives for value adding as well as increase access to financing. The message coming out clear therefore is that Africa should industrialize if sustainable economic growth is to be achieved. Aid should only come in to help finance reforms towards accelerating this domestically owned industrialization.

Since the coefficient of government size in the growth model was found to have the second largest absolute value, aid should be earmarked to support the establishment and sustenance of institutions responsible for fiscal management, including watch dogs and a strong parliament and enacting public sector management laws. This will ensure that aid is channelled to what it is originally intended for and not be fungible. The role of fiscal austerity needs not be overemphasized bearing in mind that large fiscal deficit exerts knock on effects on achievements of monetary and inflation targets. The need for proper use of donor aid and government finances is further magnified by the fact that developing countries need more resources allocated to pro poor expenditures such as health and education in order to meet Millenium Development Targets by 2015. Given that most governments cannot reduce expenditure in these sectors, it is only proper that they maintain a tight lid in the expenditures in other non key sectors, especially where it relates to the recurrent budget.Further research however should consider finding out ways through which aid could be made more effective to influence economic growth.

\section{References}

Birdsall, N. (2004). Seven Deadly Sins: Reflections on Donor Failings. Centre for Global Development Working Paper No 50.

Bolton G(2008).Aid and Other Dirty Business: An Insider Reveals How Good Intentions Have Failed the World's Poor, Ebury Press, Reading.

Burnside C. \& Dollar, D. (2000).Aid, Policies and Growth.American Economic Review,Vol 90, No 4 pp 847-868.

Cleeve, E.(2008). How Effective are Fiscal Incentives to Attract Foreign Direct Investment to Sub Saharan Africa?The Journal of Developing Areas, Vol 2 No 1, Fall 2008, pp 135-153

Clemens, M. A.,Radelet, S. \&Bhavnani, R. (2004). Counting Chickens When They Hatch: The Short Term Effect of Aid on Growth, Centre for Global Development, Working Paper No 44.

Collier, P. \&Dehn, J. (2001). Aid, Shocks and Growth" World Bank Policy Research Working Paper No 2688, World Bank, Washington $D C$.

Cordella, T. \&Ulku, H. (2004). Grants Versus loans", IMF Working Paper Number 04/161.

Devarajan, S.,Rajkumar, A.,\&Swaroop, V. (2006). Chapter 17: What Does Aid to Africa Finance? In Professor H. Beladi and Professor E Kwan Choi (ed): Theory and Practice of Aid (Frontiers of Economics and Globalization, Vol 1), Emerald Group Publishing Ltd, pp333-355.

Easterly, W. (2003), Can Foreign Aid Buy Growth? Journal of Economic Perspective,Vol 17, No 3 pp 23-48.

Gomanee, K.,Girma, S. \&Morrisesey, O. (2005). Aid Growth in Sub Saharan Africa: Accounting for Transmission Mechanisms.Journal of International DevelopmentVol 17, Issue 8 pp 1055-1075.

Killick, T., \&Foster, M. (2007).The Macroeconomics of Doubling Aid to Africa and the Centrality of the Supply Side.Development Policy ReviewVol 25, No 2 pp 167-192.

Moyo, D. (2009).Dead Aid: Why Aid Is Not Working and How There Is Another Way for Africa, Penguin Groups, London

Outtara, B.,\&StroblE (2004). Do Aid Inflows Cause Dutch Disease? A Case Study of the CFA Franc Countries Using Dynamic Panel Analysis.Development Economics Discussion Paper No 0404, University of Manchester.

Rajan, R. \& Subramanian, A. (2005).Aid and Growth: What Does the Cross Country Evidence Really Show? International Monetary Fund Working Paper No 127.

Roodman, D. (2006). Aid Project Proliferation and Absorptive Capacity.Centre for Global Development Working Paper No 75.

Ruhashyankiko, J. (2005). Why Some Countries Manage to Extract Growth from Foreign Aid? IMF Working Paper No 53, March.

Stern, N. (2002). Making the Case for Aid; in World Bank, A Case for Aid: Building a Consensus for Development Assistance (Washington: The World Bank).

Stiglitz,J. (2006).Making Globalization Work, Penguin Group, New York.

UNCTAD (2006).Economic Development in Africa, 2006: Putting Aid to Work: Some Key Issues, UNCTAD/GDS/AFR/CA/2006/1 Geneva.

UNDP (2005). Human Development Report: International Cooperation at Crossroads: Aid, Trade and Security in an Equivocal World, United Nations Development Program , New york

Wooldridge, J. (2006b).Econometric Analysis of Cross Sectional and Panel Data, Cambridge Press, Cambridge.

World Bank (2006a). Global Development Finance 2006, The Development Potential of Surging Capital Flows, Washington DC; World Bank 
